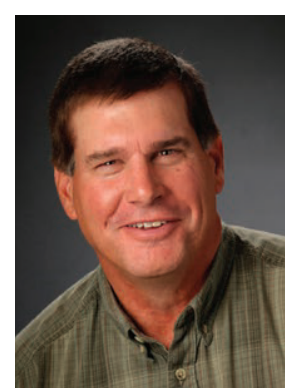

By Jeff Mosley

Browsing the
Literature

This section reviews new publications available about the art and science of rangeland management. Personal copies of these publications can be obtained by contacting the respective publishers or senior authors (addresses shown in parentheses). Suggestions are welcomed and encouraged for items to include in future issues of Browsing the Literature. Contact Jeff Mosley at jmosley@montana.edu.

\title{
Animal Ecology
}

Effects of prescribed burning on Swainson's warbler home-range size and habitat use. J. L. Everitts, T. J. Benson, J. C. Bednarz, and N. M. Anich. 2015. Wildlife Society Bulletin 39:292-300. (National Wild Turkey Federation, 625 Bonnie Lane, Conway, AR 72034, USA). In eastern Arkansas, low-intensity prescribed burns appeared to have minimal impacts on the songbird Swainson's warbler.

Evaluating the impact of gas extraction infrastructure on the occupancy of sagebrush-obligate songbirds. M. Mutter, D. C. Pavlacky, N. J. Van Lanen, and R. Grenyer. 2015. Ecological Applications 25:1175-1186. (School of Geography and Environment, Oxford Univ, Oxford OX1 3QY, England). Increasing road density negatively affected sagebrush sparrows and sage thrashers near a natural gas extraction site in Wyoming, but increasing well density did not.

Factors influencing reproductive success of ferruginous hawks in the Uintah Basin, Utah. H. L. Keough, M. R. Conover, and A. J. Roberts. 2015. Journal of Raptor Research 49:161-173. (Dept of Wildland Resources, Utah State Univ, Logan, UT 84322, USA). The level of oil development that occurred during this study did not affect ferruginous hawk reproduction. Predation by golden eagles was the limiting factor.

The influence of harvest timing on greater sage-grouse survival: a cautionary perspective. E. J. Blomberg. 2015. Journal of Wildlife Management 79:695-703. (Dept of Wildlife, Fisheries, and Conservation Biology, Univ of Maine, Orono, ME 04469, USA). The author suggests that reduced bag limits and shortened hunting seasons are better ways to decrease harvest of adult female and juvenile sage-grouse than moving hunting seasons to later in the year.

Short-term changes in summer and winter resident bird communities following a high severity wildfire in a southern USA mixed pine/hardwood forest. D. J. Brown, J. R. Ferrato, C. J. White, I. Mali, M. R. J. Forstner, and T. R. Simpson. 2015. Forest Ecology and Management 350:13-21. (US Forest Service, 5985 City Hwy K, Rhinelander, WI 54501, USA). One year after wildfire in the Lost Pines region of Texas, the richness of winter bird species increased in burned habitat, but total bird abundance remained unchanged. 


\section{Grazing Management}

Cattle grazing in semiarid forestlands: habitat selection during periods of drought. C. L. Roever, T. DelCurto, M. Rowland, M. Vavra, and M. Wisdom. 2015. Journal of Animal Science 93:3212-3225. (Agriculture Program, Oregon State Univ, One Univ Blvd, La Grande, OR 97850, USA). Despite seasonal and annual fluctuations in rainfall across 8 years, cattle habitat selection in northeastern Oregon was relatively consistent. When conditions became drier during late summer, cattle contracted their foraging site selection around water.

Climate-change adaptation on rangelands: linking regional exposure with diverse adaptive capacity. D. D. Briske, L. A. Joyce, H. W. Polley, J. R. Brown, K. Wolter, J. A. Morgan, B. A. McCarl, and D. W. Bailey. 2015. Frontiers in Ecology and the Environment 13:249-256. (Dept of Ecosystem Science and Management, Texas A\&M Univ, College Station, TX 77843, USA). Livestock grazing strategies need to be developed to minimize the adverse consequences of climate change in the southwestern United States and Texas and to capitalize on potential climateinduced opportunities in the northern Great Plains.

Improving efficiency of production in pasture- and range-based beef and dairy systems. J. T. Mulliniks, A. G. Rius, M. A. Edwards, S. R. Edwards, J. D. Hobbs, and R. L. G. Nave. 2015. Journal of Animal Science 93:2609-2615. (Dept of Animal Science, Univ of Tennessee, Knoxville, TN 37996, USA). To increase the efficiency of beef production on pastures and rangelands, the authors recommend that ranchers use genetic testing to select cows that require less energy for maintenance.

Improving soil health and productivity on grasslands using managed grazing of livestock. J. R. Russell, and J. J. Bisinger. 2015. Journal of Animal Science 93:2626-2640. (Dept of Animal Science, Iowa State Univ, Ames, IA 50011, USA). Reviews livestock grazing effects on ecological services provided by grasslands.

Grazing maintains native plant diversity and promotes community stability in an annual grassland. J. J. Beck, D. L. Hernandez, J. R. Pasari, and E. S. Zavaleta. 2015. Ecological Applications 25:1259-1270. (D. Hernandez, Dept of Biology, Carleton College, Northfield, MN 55057, USA). In California, results demonstrated that “... moderateintensity cattle grazing can be used to restrict the invasive potential of exotic grasses and maintain native plant communities in serpentine grasslands."

Intake of medusahead by sheep: influence of supplements, silica and individual animal variation. J. J. Villalba, and E. A. Burritt. 2015. Invasive Plant Science and Management 8:151-159. (Dept of Wildland Resources, Utah State Univ, Logan, UT 84322, USA). High-energy supplements did not increase medusahead use by lambs relative to unsupplemented animals.

\section{Plant Ecology}

Season of fire manipulates bud bank dynamics in northern mixed-grass prairie. M. L. Russell, L. T. Vermeire, A. C. Ganguli, and J. R. Hendrickson. 2015. Plant Ecology 216:835-846. (Texas A\&M AgriLife Extension Service, 7887 US Hwy 87 North, San Angelo, TX 76901, USA). Plant densities of blue grama, needle-and-thread grass, and western wheatgrass in eastern Montana were unaffected by prescribed fire applied in summer, fall, or spring. However, burning in any season dramatically reduced the number of active buds in needle-and-thread grass 2 years following the burn.

\section{Rehabilitation/Restoration}

Implementing strategic weed prevention programs to protect rangeland ecosystems. B. S. Smith, and R. L. Sheley. 2015. Invasive Plant Science and Management 8:233-242. (US Department of Agriculture-Agricultural Research Service, 67826-A Hwy 205, Burns, OR 97720, USA). The authors describe how to develop and implement a proactive weed prevention program on ranches or in watersheds.

Integrating herbicides and re-seeding to restore rangeland infested by an invasive forb-annual grass complex. J. Mangold, N. Orloff, H. Parkinson, and M. Halstvedt. 2015. Ecological Restoration 33:16-19. (Dept of Land Resources and Environmental Sciences, Montana State Univ, Bozeman, MT 59717, USA). Bluebunch wheatgrass and tall wheatgrass successfully established when reseeded after herbicide application with aminopyralid (Milestone) on rangeland in western Montana infested by spotted knapweed and cheatgrass.

Managing Canada thistle (Cirsium arvense) in a constructed grassland with aminopyralid and prescribed fire. G. G. Gramig, and A. C. Ganguli. 2015. Invasive Plant Science and Management 8:243-249. (Dept of Plant Sciences, North Dakota State Univ, Fargo, ND 58102, USA). Aminopyralid (Milestone) herbicide effectively controlled Canada thistle. Prescribed fire combined with aminopyralid did not increase warm-season grasses, but instead, openings were filled by the dominant cool-season grasses.

Patch-burn grazing management, vegetation heterogeneity, and avian responses in a semi-arid grassland. D. J. Augustine, and J. D. Derner. 2015. Journal of Wildlife Management 79:927-936. (US Department of AgricultureAgricultural Research Service, 1701 Centre Ave, Fort Collins, CO 80526, USA). In the shortgrass prairie of northeastern Colorado, patch-burn grazing enhanced breeding habitat for mountain plovers, but the intensity or frequency of grazing and burning did not provide enough tall and dense vegetation needed for the breeding habitat of other native grassland birds.

Wild bison as ecological indicators of the effectiveness of management practices to increase forage quality on open rangeland. D. H. Ranglack, and J. T. duToit. 
2015. Ecological Indicators 56:145-151. (Dept of Wildland Resources, Utah State Univ, Logan, UT 84322, USA). Rangeland burned 10 years previously to suppress pinyonjuniper encroachment produced higher quality forage for bison compared with either unburned open-tree-canopy areas, unburned closed-tree-canopy areas, or mechanically treated areas.

\section{Socioeconomics}

Effective weed management, collective action, and land ownership change in western Montana. L. Yung, J. Chandler, and M. Haverhals. 2015. Invasive Plant Science and Management 8:193-202. (Dept of Society and Conservation, Univ of Montana, Missoula, MT 59812, USA). Absentee landowners were much less likely to manage the weeds on their properties and less likely to use herbicides compared with resident landowners.
Why agree to a conservation easement? Understanding the decision of conservation easement granting. J. R. Farmer, V. Meretsky, D. Knapp, C. Chancellor, and B. C. Fischer. 2015. Landscape and Urban Planning 138:11-19. (Dept of Recreation, Park and Tourism Studies, Indiana Univ, Bloomington, IN 47405, USA). Compared with absentee landowners, owners of working lands or year-round residents were less likely to adopt a conservation easement without financial incentives.

Jeff Mosley is Professor of Range Science and Extension Range Management Specialist, Department of Animal and Range Sciences, Montana State University, Bozeman, MT 59717.

Rangelands 37(5):205-207

doi $10.1016 /$ j.rala.2015.08.001

(c) 2015 The Society for Range Management 